\title{
Oxidative Stress Caused by Use of Pre-emergent Herbicides in Wheat Seedlings
}

\author{
Hemlata Singh", S. Pal and A. Bhattacharya \\ Department of Agricultural Biochemistry, Bidhan Chandra Krishi Vishwavidyalaya, \\ Mohanpur, Nadia - 741252, West Bengal, India \\ *Corresponding author
}

\section{A B S T R A C T}

\begin{tabular}{|l|}
\hline Ke y w o r d s \\
$\begin{array}{l}\text { Oxidative stress, } \\
\text { Antioxidants, Wheat, } \\
\text { Total phenol, } \\
\text { Phenylalanine ammonia } \\
\text { lyase and Phenol oxidase } \\
\text { enzyme. }\end{array}$ \\
\hline Article Info \\
\hline $\begin{array}{l}\text { Accepted: } \\
19 \text { October } 2017 \\
\text { Available Online: } \\
\text { 10 December } 2017\end{array}$ \\
\hline
\end{tabular}

Keywords

Oxidative stress

Antioxidants, Wheat,

lyase and Phenol oxidase

enzyme.

Accepted:

19 October 2017

10 December 2017
Use of herbicides is indispensable for higher production of wheat crop. However, even selective, use of herbicides causes oxidative stress in plant due to production of reactive oxygen species. The aim of this study was to understand oxidative stress caused by herbicide and antioxidant adaptive response of wheat plants. Application of the recommended field dose of butachlor and pendimethalin to 10-days old wheat seedlings significantly increased total phenol content and phenylalanine ammonia lyase enzyme, compared to control, indicating adaptive response of plant to oxidative stress induced by herbicide. Recommended dose of butachlor, also significantly increased phenol oxidase enzyme activity over control whereas, application of the recommended field dose of pendimethalin significantly decreased phenol oxidase enzyme activities compared to control, which may suggest that pendimethalin treatment resulted in severe stress which damaged plant capacity to control the oxidative stress induced by herbicide.

\section{Introduction}

Wheat (Triticum aestivum L.) is one of the important grain crops produced worldwide, occupying 17 percent of the total cultivated land in the world. Wheat is the staple food for 40 percent of the world's population (Peng et al., 2011). Wheat provides $21 \%$ of the food calories and $20 \%$ of the protein to more than 4.5 billion people in 94 developing countries (Braun et al., 2010). Weed infestation is a major bottleneck to higher wheat productivity, and accounts for more than $48 \%$ loss of potential wheat yield (Khan and Haq, 2002). Wheat is infested by diverse weed flora and use of herbicide is very popular for controlling them, as herbicides are selective, cost effective, and easy to apply and flexibility in application time. In India $96 \%$ of herbicides are moderately toxic, while more than $70 \%$ insecticides are extremely toxic (NRCWS, 2007). Complexity and diversity of weed flora requires more than one herbicide either in sequence or as mixture for controlling them (Paswan et al., 2017).

These herbicides are xenobiotic, which causes oxidative stress in plant leading to generation of reactive oxygen species (ROS), they react with lipids, proteins, pigments and nucleic acids and cause lipid peroxidation, membrane damage and inactivation of enzymes, thus affecting cell viability (Aravind and Prasad, 2005). However, plants have a system for 
scavenging of ROS to protect cells from oxidative damage composed of nonenzymatic antioxidants, e.g., phenols, glutathione (GSH) and ascorbate (AsA) and enzymatic antioxidants, e.g., superoxide dismutase (SOD), catalase (CAT) and ascorbate peroxidase (APX) (Nemat Alla et al.,2008; Zushi and Matsuzoe, 2009). Singh et al., (2013) worked on effect of four herbicides namely isoproturon, phenoxapropethyl, sulfosulfuron on biochemical changes in wheat and reported that catalase and peroxidase activities in leaves were significantly increased due to herbicides over untreated check, minimum increase was observed with sulfosulfuron, while isoproturon had maximum increase.

The effects of glyphosate (from 0.01 to 10 $\mathrm{mM}$ ) on characteristics of oxidative stress (content of hydrogen peroxide and malondialdehyde, decrease in chlorophyll level) and activities of antioxidant enzymes (catalase, peroxidase, superoxide dismutase, ascorbate peroxidase, glutathione reductase, glutathione S-transferase) in pea, wheat, duckweed, and Vignaradiata were reported by different studies (Miteva et al., 2005; Basantani et al., 2011).

The cooperative functions of these antioxidant activities make it possible to scavenge the ROS and maintain the redox status of the cell. Pendimethalin and butachlor are two commonly used herbicides in wheat. The herbicide butachlor is a pre-emergence, chloroacetanilide herbicide, which affects seed germination, lipid metabolism, pigment and gibberellic acid synthesis, cell division, cell permeability, mineral uptake and disturb the absorption and incorporation of amino acid into protein (Kearney et al., 1988), very long chain fatty acid (VLCFA) synthesis (Boger et al., 2000). Pendimethalin is also pre-emergence herbicide and is used for control of broadleaf weeds in crop fields. It belongs to di-nitroaniline group and has low water solubility, mobility and low volatility (Schleicher et al., 1995). It acts on cell division by blocking mitotic division and causing accumulation of abnormal microtubular structures (Fennell et al., 2006).

It is very important to understand how plants defend themselves and respond to various stresses for developing more resistant crop varieties, thereby increasing crop yield. In the view of above, this experiment was carried out with an objective to study herbicide induced oxidative stress of two herbicides pendimethalin and butachlor at recommended dose on wheat seedling and its adaptive antioxidant response.

\section{Materials and Methods}

Grains of wheat (Triticum aestivum L, PBW343) were soaked for 8 hours and germinated in soil in pots $(30 \mathrm{~cm}$ height $\times 30 \mathrm{~cm}$ diameter). When seedlings were 10-days-old, pots were divided into three groups, one to serve as control, one for pendimethalin treatment at recommended field dose $(1 \mathrm{~kg}$ ai/ha) and other one for butachlor treatment at recommended field dose (1 kg ai/ha).

Of each herbicide, the required doses to be added to the surface area per pot were calculated in relation to the rate per hectare. Then the herbicide quantity was solublized in a suitable amount of water, and applied as foliar spray to whole plant with mechanical sprayer, in one direction and cross wise.

Leaf sample of wheat seedlings was collected from each treatment replications 3 days after treatment. A portion of leaf samples were immediately used without drying for enzyme assay and the rest was oven dried at $40{ }^{\circ} \mathrm{C}$ till constant weight and ground using an electric grinder and kept in the polythene lock bag for the total phenol estimation. 


\section{Biochemical analysis}

\section{Non-enzymatic antioxidants}

\section{Total Phenol estimation}

The total phenol content of wheat leaf was determined using Folin-Ciocalteau Reagent (FCR) (Vinson et al., 1998). To determine total phenol present in wheat leaf, dry sample $(0.1 \mathrm{~g})$ was extracted with $15 \mathrm{ml}$ of $1.2 \mathrm{~N} \mathrm{HCl}$ in $50 \%$ aqueous methanol and heated at $90{ }^{\circ} \mathrm{C}$ for 2 hours. After cooling the extracted material was centrifuged at $10,000 \mathrm{rpm}$ for 30 minutes.

The supernatant was decanted off in a beaker and evaporated to dryness. The crude extract was diluted to $25 \mathrm{ml}$ with $1.2 \mathrm{~N} \mathrm{HCl}$ in $50 \%$ aqueous methanol. For the estimation of phenol, suitable amount of aliquot was diluted to $3 \mathrm{ml}$ with distilled water in a test tube, 0.5 ml FCR was added to it.

After 3 minutes $2 \mathrm{ml}$ of $10 \%$ sodium carbonate was added. Then test tubes was warmed at about $60-70{ }^{\circ} \mathrm{C}$ for 5 minutes in a water bath. The solution was cooled and the absorbance was read at $650 \mathrm{~nm}$ and the phenol content was determined using a standard curve made from gallic acid. The phenol content is expressed as mg gallic acid equivalent per gram dry weight (mg GAE/g DW).

\section{Enzymatic antioxidant}

\section{Phenol oxidase enzyme assay}

Phenol oxidase was estimated as per the modified method of Shannon et al., (1966). The enzyme extract was extracted by grinding $1 \mathrm{~g}$ fresh leaf tissue with $10 \mathrm{ml}$ of $0.1 \mathrm{M}$ Sodium Phosphate buffer, $\mathrm{pH} 7.5$ containing $2 \%$ polyvinylpyrrolidone and $0.25 \%$ Triton$\mathrm{X}$, in a pre-chilled mortar and pestle. The extracted sample was centrifuged at 10,000 rpm for 30 minutes at $4^{\circ} \mathrm{C}$ and the supernatant was used as the enzyme source which was stored in an ice bath until the assay was carried out. Phenol oxidase activity was estimated by mixing $0.05 \mathrm{ml}$ chilled enzyme extract with $2.8 \mathrm{ml}$ reaction mixture $(0.15 \mathrm{ml}$ of $4 \%$ Guaiacol dissolved in methanol and $2.65 \mathrm{ml}$ sodium potassium buffer $(0.1 \mathrm{M}) \mathrm{pH}$ 7.5). Reaction was initiated by adding $0.15 \mathrm{ml}$ of $\mathrm{H}_{2} \mathrm{O}_{2}(1 \%)$. The change in activity was measured at $470 \mathrm{~nm}$. Initial absorbance was read and then at every at every 30 seconds interval up-to 3 minutes readings were taken. The phenol oxidase activity was calculated by using an absorption coefficient $\left(26.6 \mathrm{mM}^{-}\right.$ ${ }^{1} \mathrm{~cm}^{-1}$ ) at $470 \mathrm{~nm}$ for the tetra-guaiacol. Enzyme activities were expressed as $\mu \mathrm{mol}$ of guaiacol oxidized/min/g of leaf sample.

\section{Phenylalanine Ammonia Lyase (PAL) enzyme assay}

PAL activity was estimated as per the modified method of Burell and Rees (1974). The enzyme was extracted by grinding $1 \mathrm{~g}$ fresh leaf tissue with $10 \mathrm{ml}$ of $0.1 \mathrm{M}$ Sodium Phosphate buffer, pH 7.5 containing 2\% polyvinylpyrrolidone and $0.25 \%$ Triton-X, in a pre-chilled mortar and pestle. The extracted sample was centrifuged at 10,000 rpm for 30 minutes at $4{ }^{\circ} \mathrm{C}$ and the supernatant was used as the enzyme source which was stored in an ice bath until the assay was carried out. PAL activity was estimated by mixing $0.1 \mathrm{ml}$ chilled enzyme extract with $1.9 \mathrm{ml}$ of Tris$\mathrm{HCl}$ buffer $\left(\begin{array}{ll}0.1 & \mathrm{M}\end{array}\right) \mathrm{pH} \quad 8.8$ and $1 \mathrm{ml}$ phenylalanine $(0.01 \mathrm{M})$. The change in activity was measured at $270 \mathrm{~nm}$. Initial absorbance was read and then at every 5minute interval up-to 30 minutes readings were taken. The PAL enzyme activity was calculated by using standard curve of transcinnamic acid at 270nm. Enzyme activities were expressed $\mu \mathrm{mol}$ trans-cinnamic acid $\mathrm{produced} / \mathrm{h} / \mathrm{g}$ of leaf sample. 
Fig.1 Effect of herbicide on total phenol content in leaves of wheat seedlings

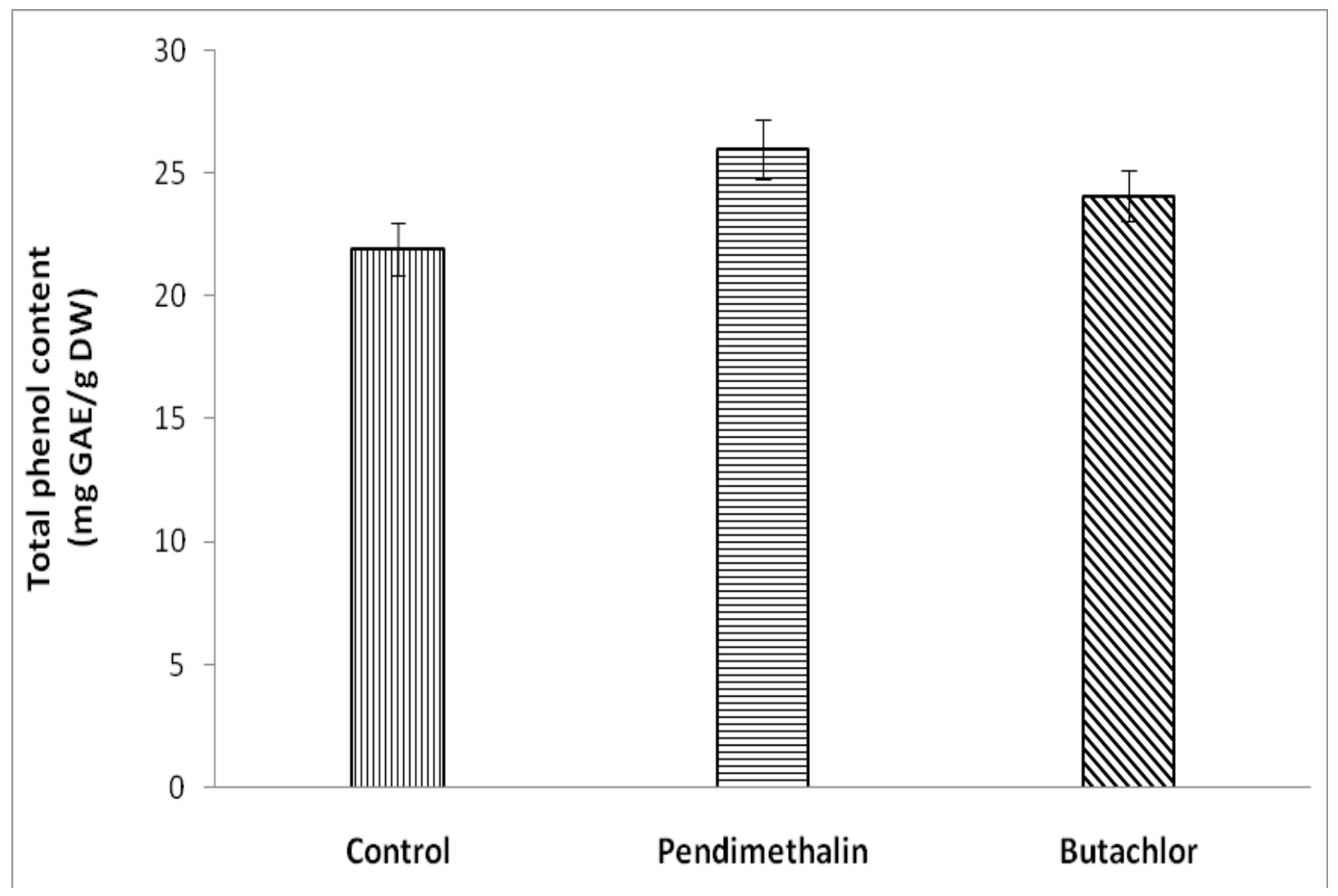

Fig.2 Effect of herbicide on PAL enzyme activity in leaves of wheat seedlings

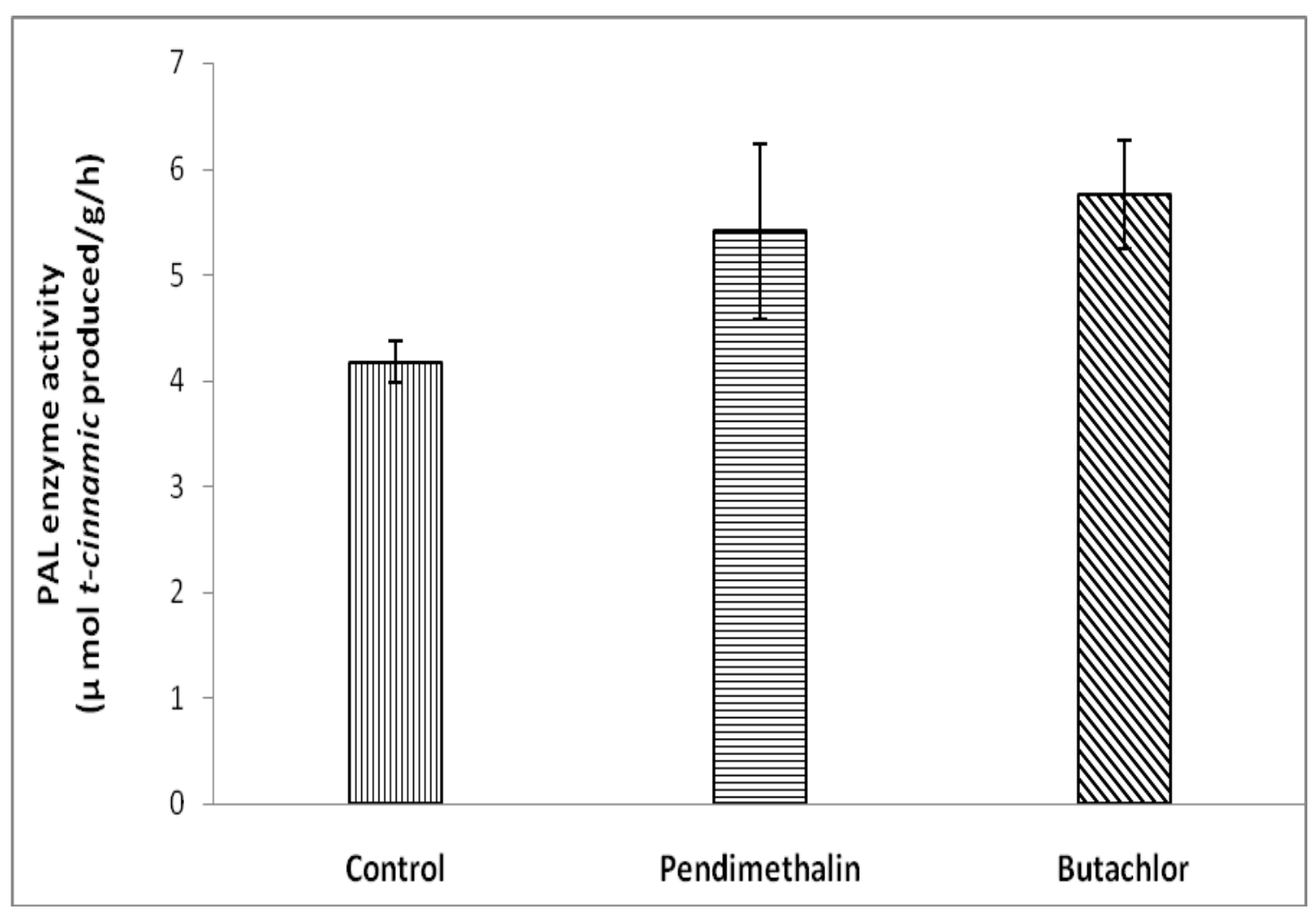


Fig.3 Effect of herbicide on Phenol oxidase enzyme activity in leaves of wheat seedlings

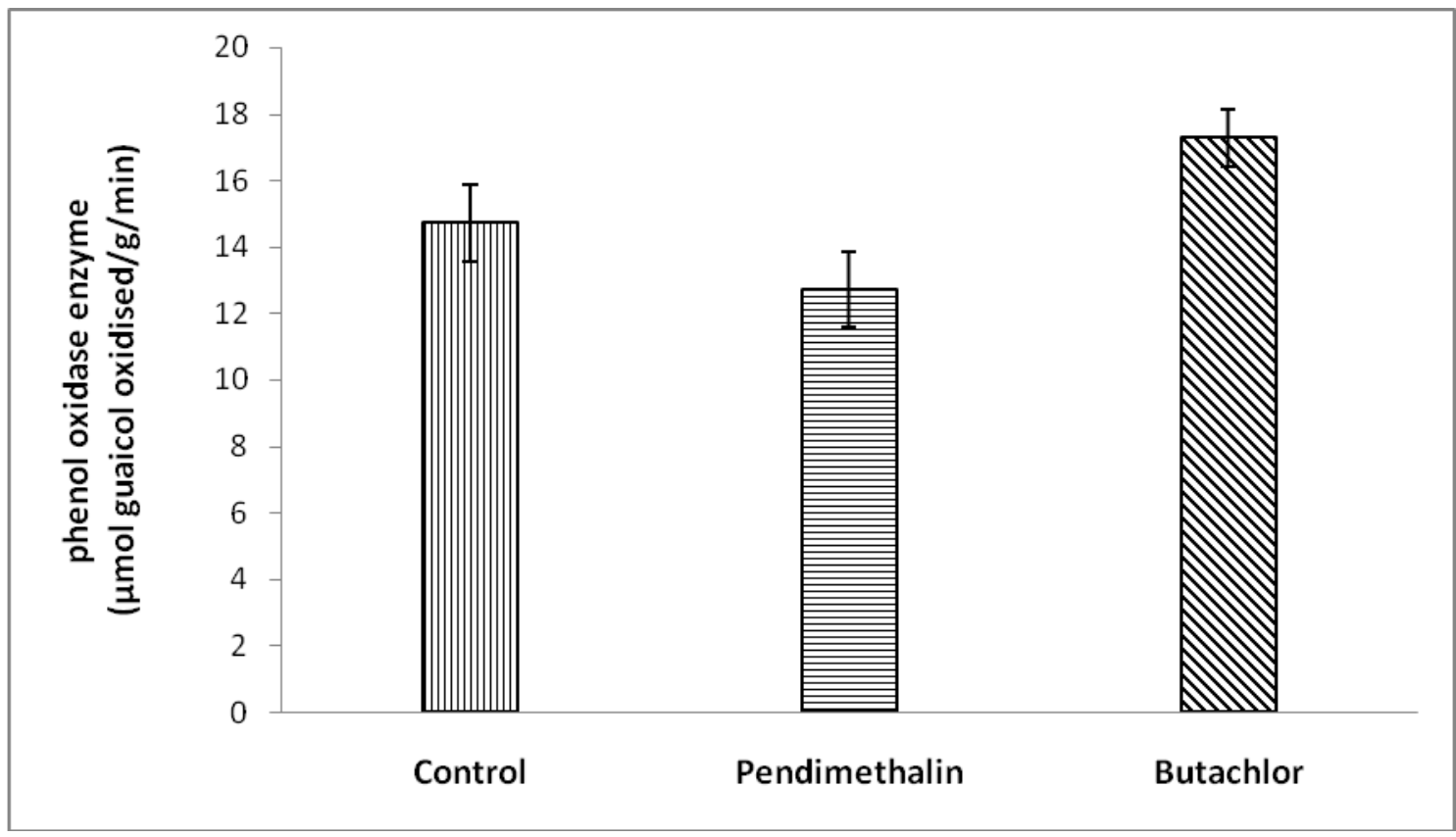

\section{Results and Discussion}

\section{Non-enzymatic antioxidant: Total phenol}

Figure 1 represents effect of two herbicides on total phenol content of wheat seedlings. The results indicated that there is a significant increase in total phenol in herbicide treated plants over control. Many studies have shown that phenolic compounds present a great antioxidant potential, the increase in phenolic compounds increases the plant antioxidant activity due to the reducing properties and chemical structure of these molecules (Sousa et al., 2007). A Similar stimulation of total phenol in wheat in response to application of Derby, a mixture of Florasulan and Flumetsulan at sub-lethal doses has been reported by El-Rokiek et al., (2012).

Thus, the enhanced level of TP in response to the application of these herbicides can be ascribed to stress response which can trigger the activities of enzymes of phenol metabolism leading to accumulation of higher phenol content.

\section{Enzymatic antioxidants}

A number of antioxidant enzymes play important role in quenching reactive oxygen species induced by herbicides. Geetha et al., (2017) also reported that antioxidant enzymes superoxide dismutase and peroxidase activity increases during stress. During this study, it was observed that toxicity of the herbicides resulted in significant change in the activity of PAL enzyme (Fig. 2) and phenol oxidase enzyme (Fig. 3). PAL, a key enzyme in the phenylpropanoid pathway, is involved in the defense response of plant cells. Thus, PAL enzyme has been generally recognized as a biomarker of environmental stress in different plant species (MacDonald and D'Cunha 2007). It is observed that PAL enzyme activity significantly increased in herbicide treated plants over control, increased PAL activity could be a response to the cellular damage induced by herbicide stress. Similar results were reported by Nemat Alla and Younis (1995) in maize and soybean seedling with alachlor and rimsulfuron herbicides. So, it seems that, the enhancement of PAL 
activity could be related to the implication of this enzyme in the plant response to herbicide stress. In case of phenol oxidase enzyme, butachlor treatment resulted in increase in enzyme activity over control, but pendimethalin treatment slightly decreases in enzyme activity over control. It may suggest that plant experienced moderate stress due to butachlor treatment which resulted in increase in enzyme activity, whereas pendimethalin treatment resulted in severe stress which damaged plant capacity to control the oxidative stress induced by herbicide.

Based on the foregoing, it can be concluded that the herbicide treatments induce oxidative stress in wheat seedlings, stimulating the secondary metabolism of wheat seedlings by synthesis of antioxidant, enzymatic and nonenzymatic molecules. Increased total phenol, PAL and phenol oxidase enzyme suggest the tolerance capacity of the plant to protect themselves from oxidative damage. Such a test may be useful for explaining the herbicide tolerance mechanisms of wheat plant. The various parameter studied in this investigation can also be used as biomarkers of herbicide butachlor and pendimethalin exposure.

\section{References}

Aravind, P. and Prasad, M.N. 2005. Modulation of cadmium-induced oxidative stress in Ceratophyllum demersum by zinc involves ascorbateglutathione cycle and glutathione metabolism. Plant Physiology and Biochemistry, 43:107-116.

Basantani, M., Srivastava, A. and Sen, S. 2011. Elevated antioxidant response and induction of glutathione S-transferase after glyphosate treatment in Vigna radiata (L.) Wilczek, Pesticide Biochemistry Physiology, 99: 111-117.

Boger, P., Matthes, B. and Schamalfub, J. 2000. Review-Towards the primary target of chloroacetamides new findings pave the way. Pest Management Science, 56:497-508.

Braun, H.J., Atlin, G. and Payne, T. 2010. Multi-location testing as a tool to identify plant response to global climate change. In: Reynolds, CRP (ed) Climate change and crop production, CABI, London, UK.

Burrell, M.M. and Rees, T.A. 1974. Metabolism of phenylalanine and tyrosine in rice leaves infected by Pyricularia oryzae. Physiological Plant Pathology, 4: 497- 508.

El-Rokiek, Kowthar G., Mohamed, E. ElAwadi and Abd El-Wahed, M.S.A. 2012. Physiological responses of wheat plants and accompanied weeds to derby herbicide and $\beta$-sitosterol bioregulator. Journal of Applied Research Science, 8(4): 1918-1926.

Fennell, B. J., Naughton, J. A., Dempsey, E, and Bell, A. 2006. Cellular and molecular actions of dinitroaniline. Molecular and Biochemical Parasitology, 145(2):226-38.

Geetha, A., A. Sivasankar, P. Saidaiah and Lakshmi Prayaga. 2017. Antioxidant Enzyme Response in Water Stress Sunflower Genotypes. International Journal Current Microbiology and Applied Science, 6(5): 138-146.

Goyal, A. and Prasad, R. (2010). Some Important Fungal Diseases and their Impact on wheat Production. In: Arya A, Perelló AEV (eds) Management of fungal plant pathogens. CABI. pp.362.

Kearney, P.C. and Kaufman, D.D. 1998. Herbicides: Chemistry, degradation and mode of action. Acta Physiologiae Plantarum, 24:97-113.

Khan, M. and Haq, N. 2002. Wheat crop yield loss assessment due to weeds. Sarhad Journal of Agriculture, 18: 449-453.

MacDonald, M.J. and D'Cunha, G.B. 2007. A modern view of phenylalanine 
ammonia-lyase. Biochemistry and Cell Biology, 85: 273-282.

Miteva, L., Tsoneva, J., Ivanov, S. and Alexieva, V. 2005. Alterations of the content of hydrogen peroxide and malondialdehyde and the activity of some antioxidant enzymes in the roots and leaves of pea and wheat plants exposed to glyphosate.Comptes Rendus De l'Academie Bulgare Des Sciences58 : 723-728.

Nemat Alla, M. M., Badawi, A. M., Hassan, N. M., El-Bastawisi, Z. M. and Bardran, E. G. 2008. Effect of metribuzin, butachlor and chlorimuron-ethyl on amino acid and protein formation in wheat and maize seedlings. Pesticide Biochemistry and Physiology,90: 8-18.

Nemat Alla, M.M. 1995. Influence of imazethapyr on the kinetics of ribulose 1,5-bisphosphate carboxylase and on the nitrogenous components in Glycine max.Egypt Journal of Botany, 35:7789.

NRCWS (2007). NRCWS perspective plan, vision. National research center for weed science (NRCWS), Jablapur, India 56-59.

Paswan, A.K., Mandal, D., Kumar, J. and Kumar, R. 2017. Influence of Weed Management Practices on Productivity of Wheat (Triticum aestivum L.) under Middle Indo-Gangetic Plains of Eastern India. International Journal of Current Microbiology and Applied Science, 6(6): 2486-2491.
Peng J., Sun, D. and Nevo, E. 2011. Wild emmer wheat, Triticum dicoccoides, occupies a pivotal position in wheat domestication. Australian Journal of Crop Science, 5:1127-1143.

Schleicher, L.C., Shea, P. J., Stouggaard, R.N. and Tupy, D. R. 1995. Efficacy and dissipation of dithiopyr and pendimethalin in perennial ryegrass (Lolium perenne) turf. Weed Science, 28:105-110.

Shanon, J. 1966. Methods of enzymatic analysis. 2nd ed. Academic Press, New York

Singh, S. B., Das, T. K. and Kulshrestha, G. 2013. Persistence of herbicide fenoxaprop and its acid metabolite in soil and wheat crop. Journal of Environmental Science and Health. 48: 320-324.

Sousa, C. M. M. 2007. Fenóis totais e atividade antioxidante de cinco plantas medicinais. Quimica Nova, 30(2):351355.

Vinson, J. A., Hap, Y., Su, X. and Zubik, L. 1998. Phenolic antioxidant quantity and quality in foods: vegetables. Journal of Agriculture Food Chemistry, 46: 36303634.

Zushi, K. and Matsuzoe, N. 2009. Seasonal and cultivar differences in salt-induced changes in antioxidant system in tomato. Scientia. Horticulturae.120:181187.

\section{How to cite this article:}

Hemlata Singh, S. Pal and Bhattacharya, A. 2017. Oxidative Stress Caused by Use of Preemergent Herbicides in Wheat Seedlings. Int.J.Curr.Microbiol.App.Sci. 6(12): 2580-2586. doi: https://doi.org/10.20546/ijcmas.2017.612.299 